\title{
Análisis de necesidades: caso de estudio, para la innovación curricular en un curso ESP
}

\section{Needs Analysis: Case Study for Curricular Innovation in an ESP Course}

\author{
David Antonio Ureña Lara. ${ }^{\text {, Diana Carolina Campaña Días. }}{ }^{2}$ \& Maria Yadira Cardenas \\ Moyano. ${ }^{3}$
}

\section{Recibido: 11-12-2019 / Revisado: 02-01-2020 /Aceptado: 16-01-2020/ Publicado: 07-02-2020}

\begin{abstract}
.
DOI: $\underline{\text { https://doi.org/10.33262/concienciadigital.v3i1.1.1135 }}$

The present scientific article explored the students' perceptions of an English for Specific Purposes (ESP) English course in the Medicine career at Escuela Superior Politécnica de Chimborazo. Besides, this research had as its main objective to perform a Needs Analysis for students of the Medicine career in order to identify their needs, wants and lacks in concordance with their English learning for their future professional lives. To this end, questionnaires were administered to seventy six students of the Medicine career in order to obtain relevant information about the student's perceptions about ESP to identify and propose a solution for the needs, wants (performance) and lacks (causes) of their English course. Thus, the Needs Analysis was conducted with the perceptions obtained from the participants which responses were related to the implementation of the ESP approach in their course. The main findings of this research are related to the basic principles of ESP, which are the future needs of the English language, ESP content, ESP language skills and the use of ESP for student's future professional lives. The analysis of student perceptions through the Needs Analysis application is the main reference point for the implementation of an ESP course for future syllabus implementation and innovations of the career curriculum.
\end{abstract}

Keywords: ESP methodology, Needs Analysis

\footnotetext{
${ }^{1}$ Escuela Superior Politécnica de Chimborazo, Facultad de Salud Pública. Riobamba, Ecuador., david.urenia@espoch.edu.ec

${ }^{2}$ Escuela Superior Politécnica de Chimborazo, Facultad de Salud Pública. Riobamba, Ecuador., diana.campania@espoch.edu.ec

${ }^{3}$ Escuela Superior Politécnica de Chimborazo, Facultad de Salud Pública. Riobamba, Ecuador., yadira.cardenas@espoch.edu.ec
} 


\section{Resumen.}

El presente artículo científico exploró las percepciones de los estudiantes de un curso de inglés con fines específicos (ESP) en la carrera de medicina en la Escuela Superior Politécnica de Chimborazo. Además, esta investigación tuvo como objetivo principal realizar un análisis de necesidades para estudiantes de la carrera de Medicina con el fin de identificar sus necesidades y carencias en concordancia con su aprendizaje de inglés para sus futuras vidas profesionales. Con este fin, se administraron cuestionarios a setenta y seis estudiantes de la carrera de Medicina con el fin de obtener información relevante sobre las percepciones de los estudiantes sobre ESP para identificar y proponer una solución para las necesidades, deseos (rendimiento) y carencias (causas) de su curso de inglés. Por lo tanto, el análisis de necesidades se realizó con las percepciones obtenidas de los participantes cuyas respuestas estaban relacionadas con la implementación del enfoque ESP en su curso. Los principales hallazgos de esta investigación están relacionados con los principios básicos de ESP, que son las necesidades futuras del idioma inglés, el contenido ESP, las habilidades lingüísticas ESP y el uso de ESP para la vida profesional futura de los estudiantes. El análisis de las percepciones de los estudiantes a través de la implementación del análisis de necesidades es el principal punto de referencia para la aplicación de un curso ESP y la implementación de un sílabo e innovar el plan de estudios de carrera.

Palabras claves: Metodología ESP, Análisis de necesidades.

\section{Introduction}

English for Specific Purposes, abbreviated by scholars as ESP, refers to the teaching of English for a utilitarian purpose (Mackay, 1978). Specifically, an ESP approach to teaching English is used to develop specific language skills using real situations, which allows students to use English in their future profession and comprehend the language concerning their future professional fields. Broadly, students start their English instruction "not because they are keen on learning English Language or even English culture, but because of their need for study or work purposes." (Robinson, 1980: 6). For the principles of ESP to be fulfilled, each aspect of ESP is interwoven into the medium of instruction for specific purposes, although the comprehension of the language, in this case, English, is emphasized over other skills.

Nowadays, ESP has gained attention among other approaches and methodologies for English instruction. This trend has witnessed a substantial upwelling in popularity across different geographical contexts. In addition, it has been increasingly considered by Ministries of Education as an innovative approach to teaching modern languages and as a motivational approach used to teach for the language used in professional contexts.

For this reason, as for any ESP course, the first step to this scientific article was to carry out a 
Needs Analysis; this was done in order to know the students' perceptions about the ESP methodology and to identify the students' interest in an ESP course, the students' deficiencies as well as their strengths in the specific area of language skills. It is only after this analysis has been conducted that we can determine course elements, such as the objectives of the syllabus and the selection of content that meets the students' needs. Thus, this Needs Analysis will be the foundation to develop Units of Study as well as Syllabus according to the research findings.

Despite the overwhelming of new and innovative methods for English teaching most of the institutions in Ecuador are not familiarized with the current tendencies for their application. This research focused on the application of Needs Analysis for an ESP course gathering students' perceptions about the ESP methodology application.

Thus, the findings will allow for the improvement of the current syllabus and the development of units of study. In this way, many other institutions may use the same model to introduce the ESP method in their English syllabus. Many different types of research with the same purpose have been conducted world wide which have found valuable pieces of evidence, students do not think there is a real need for learners to study English. According to a research conducted in the University of TELMEC (2016), students identify English as an obstacle as well as a bridge for their future professional needs. The use of English for communication is their most significant concern. Students also manifested that they needed English for specific professional purposes, but they focused most of their efforts on the mastery of language skills.

The research also sheds light on the fact that learners need ESP courses to learn how to communicate effectively in English. Hence, as it can be deducted, there is still a major concern with regards to what needs to be done before designing an ESP course, considering what learners need for their future professional lives. In this sense, there is a gap in literature concerning how Needs Analyses can be implemented in all areas of study in order to improve the quality of ESP courses conducted in Ecuador and other countries. This investigation has been conducted in the Ecuadoran context, thus, it serves as a basis for the implementation of a Needs Analysis approach to ESP courses in this country and in other places.

This scientific article shows the benefits of performing a Needs Analysis, according to the model presented by Barkeley (2017), gathering students' perceptions about ESP methodologies used at university level. To do so, the characteristics of the ESP course were identified with regards to the future language needs, the content, the language skills, and its usage on which the investigation focused to perform the Needs Analysis. There have been many projects in the field focusing on the same characteristics, some of them being more detailed than others. Most projects related to this have identified core principles of ESP courses as well as learners' performance and needs. Furthermore, it has been stated that students' main concern it is related to the language skills usage. Hence, the final aim of this investigation is to contribute as a cornerstone of curriculum innovation 
following the process of performing a Needs Analysis according to the students' perceptions about the principles of the ESP methodology. Thus, it can be used for new English teaching language methods like CLIL (Content and Language Implemented Learning). Mackay (1978) strenuously defends that a curriculum cannot be implemented without performing a Needs Analysis as a first step because the students have to know and clarify their learning needs before starting the learning instruction. Hence, the investigation considers this statement as its core in which lies its importance and relevance.

Having stated the final purpose of this research, the general objective of this investigation is to explore wants, needs and lacks regarding learning English for university students of English at Medicine career at Escuela Superior Politécnica de Chimborazo through a needs analysis approach to ESP.

\section{Methodology}

This study explores the English linguistic and nonlinguistic needs for an ESP program for undergraduate students in the career medicine at Escuela Superior Politécnica de Chimborazo. The study considers the perspectives of students from the academic contexts involved in this study.

A Quantitative paradigm for this investigation was selected, which corresponds to the model of Needs Analysis used for this investigation. According to Creswell (1994), there are some core principles which can be identified for any quantitative investigation. First of all, the categories or units of analysis for this kind of research are pre-conceived or predeveloped for participants' responses; this way, the researcher can clearly identify an objective.

Second, this investigations collect information or data based on facts and students perceptions; however, in doing so, the number of responses can be limited, as the investigation is usually time limited because the needs of the students can vary according their level of instruction. In third place, these investigations can be useful to identify data patterns or common needs or problems; thus, there is a distinction and discrimination of the needs presented by learners. Finally, it is considered that the primary goal of the quantification of the data is to allow generalizations of results from a sample to an entire population of interest and the measurement of various views and opinions. For these reasons outlined, this investigation was framed under a quantitative paradigm, following a descriptive and exploratory design.

This study also adopted a case study approach to capture the complex reallife dimensions in the Medicine career. The case study approach provides a broad description and analysis of a limited system or multiple bounded systems (Hood, 2009; Merriam, 1998; Stake, 1995). This approach focuses on "understanding complex phenomena while allowing the investigation to retain the holistic and meaningful characteristics of the reallife context." (Yin, 2003: 13). Berg (2009) has 
described case studies as an approach capable of examining simple circumstances, with units of analysis; this in turn entails using a variety of lines of actions in its data gathering segments and can make use of and contribute to the application of theory (Berg, 2009). Within the educational and second language teaching research areas, Chapelle and Duff (2003) have defined case studies by teacher-researchers as the study of a person, either a teacher or a student. In the present study, a case study refers to the ESP course implemented in the Medicine career at Escuela Superior Politécnica de Chimborazo. The trend towards using case studies in the second language teaching area is growing because it provides a framework for the close and extended analysis of a particular case (Hood, 2009). The findings from a case study enable a rich description of a personal and pedagogical nature which cannot be captured by other methods (Miller, 1997). The significant advantages of the case study approach are that it can present extensive data in an accessible form. It can also provide flexibility in the use of various data collection methods and it can be used in practically any kind of social setting (Singh et al., 2015).

The research paradigm that remarks the importance of this study, and then the research framework is illustrated. The description of the research participants is followed by the data collection procedures and data analysis.

Needs Analysis is a systematic process that it is set to present the current state of a situation and demonstrate that there are many solutions to achieve the desired state. The "Need" is the gap between what "should be" and "what is" determine if there is a gap in performance, the gap, possible solutions. (Berkeley Lab Training; 2017)

\section{Phase 1: describing the desired performance}

The initial step in the Needs Analysis Process is to describe the desired performance and the optimal route to achieve it. To sum up, this relates to determining the skills, behaviors, and knowledge to perform an activity adequately. The steps to follow in this case are: (a) step 1: describing the group of students; (b) step 2: describing the desired status; (c) step 3: describing the need; (d) step 4: describing expectations for performance.

\section{Phase 2: determining the current performance}

The next step is to determine what performance is (in the classroom). The analysis of the situation can be achieved by applying data collector instruments.

\section{Phrase 3: describing performance gaps and causes}

The following table provides an example for this process: 
Vol. 3, N², p.118-132, abril - junio, 2020

Table 1. Berkeley Lab Training (2017: 2)

\begin{tabular}{lllll}
\hline $\begin{array}{l}\text { Performance } \\
\text { expectation } \\
\text { (WANTS) }\end{array}$ & $\begin{array}{l}\text { Gap } \\
\text { (Need) }\end{array}$ & $\begin{array}{l}\text { Causes } \\
\text { (Lacks) }\end{array}$ & Consequence & $\begin{array}{l}\text { Difficulty } \\
\text { correct to } \\
\text { medium, high] } \\
\text { [low, }\end{array}$ \\
\hline $\begin{array}{l}\text { List } \\
\text { performance } \\
\text { expectation }\end{array}$ & a & $\begin{array}{l}\text { List the } \\
\text { Need }\end{array}$ & $\begin{array}{l}\text { List causes (which } \\
\text { are the lacks that for not performing at difficulty to } \\
\text { inhibit the process) }\end{array}$ & $\begin{array}{l}\text { desired level } \\
\text { correct (optional) }\end{array}$ \\
\hline
\end{tabular}

\section{Phase 4: Identifying solutions}

In this section, the researcher can determine which needs are the most critical and which possible solutions are. For this, the following steps are carried out: (a) step 1: identifying solutions and describing possible solutions bearing in mind the acceptability and feasibility of the process; (b) step 2: selecting solutions according to all the information gathered in the Needs Analysis process; and (c) step 3: stating recommendations. The following table is an example of how to select solutions.

Table 2: Berkeley Lab Training (2017: 3)

\begin{tabular}{ll} 
ause (Lack) & Solution type \\
\hline Lack of knowledge / skill & Teaching process, future job performance \\
Lack of information / feedback & What type of feedback and method to provide
\end{tabular}

\section{Results}

Concerning the data obtained from questionnaires administered for gathering students' perceptions about the ESP methodology. To fulfill this objective, the participants of this investigation were asked to answer questions which reflect their perceptions and background knowledge of ESP course implemented at Medicine career. This questionnaire was adapted from the model presented by Boroujeni (2013). Students' answers correspond to 10 categories which were part of the questionnaire administered. As the participants were asked to state their perceptions through the use of statements related to the Needs Analysis questionnaire, the categories, and therefore units of analysis, were preconceived. Thus, ten categories will be addressed and analyzed in this section:

1. ESP for future English needs

2. ESP methodology comprehension

3. Language skills and content in ESP 
4. ESP outside classroom

5. ESP methodology level of difficulty

6. $\quad$ ESP language learning

7. ESP usage for different English situations

8. $\quad$ ESP materials implementation

9. $\quad$ ESP language for specific purposes

10. ESP meets future professional needs

In addition, the following table shows the statements which participants had to rate according to five indicators in order to comply with the task for this specific objective. The indicators for this questionnaire and for each of the statements participants had to rate were (a) non satisfactory; (b) little satisfactory; (c) neutral; (d) satisfactory; and (e) very satisfactory. These indicators were then summarized into two: satisfactory and Non-satisfactory. This was done in order to simplify the data obtained from the participants' answers and for the sake of the analysis.

The following table represents the seventy-six participants' answers for the ten statements presented. It also shows the 5 indicators as for the complete questionnaire. This table presents all the information as for the participants responses to the categories above mentioned:

Table 3. Participants' responses to the Questionnaire

\begin{tabular}{|c|c|c|c|c|c|c|}
\hline Questions & Non-S. & Little-S. & Neutral & S. & Very-S. & Sum \\
\hline $\begin{array}{l}\text { 1. Esp is useful for my future english language } \\
\text { needs }\end{array}$ & 7 & 11 & 12 & 19 & 27 & 76 \\
\hline $\begin{array}{l}\text { 2. Esp approach was easy to comprehend and } \\
\text { handle }\end{array}$ & 18 & 14 & 2 & 23 & 19 & 76 \\
\hline $\begin{array}{l}\text { 3. Esp approach maintain a balance between lan- } \\
\text { guage skills }\end{array}$ & 9 & 12 & 8 & 26 & 21 & 76 \\
\hline $\begin{array}{l}\text { 4. The information learned with esp could be used } \\
\text { outside classroom }\end{array}$ & 5 & 11 & 10 & 28 & 22 & 76 \\
\hline $\begin{array}{l}\text { 5. Learning english is an enjoyable challenge } \\
\text { with esp }\end{array}$ & 8 & 9 & 11 & 29 & 19 & 76 \\
\hline 6. Content presented in esp class is significant & 11 & 9 & 2 & 22 & 32 & 76 \\
\hline $\begin{array}{l}\text { 7. Esp content allows interaction in different con- } \\
\text { texts }\end{array}$ & 2 & 15 & 19 & 19 & 21 & 76 \\
\hline $\begin{array}{l}\text { 8. Materials of esp approch are good enough to } \\
\text { comprenhend content }\end{array}$ & 5 & 3 & 29 & 19 & 20 & 76 \\
\hline $\begin{array}{l}\text { 9. Esp approach allows a better comprehension } \\
\text { of english language }\end{array}$ & 1 & 7 & 18 & 19 & 31 & 76 \\
\hline $\begin{array}{l}\text { 10. Esp is appropiate for metting future english } \\
\text { needs }\end{array}$ & 1 & 12 & 16 & 29 & 18 & 76 \\
\hline TOTAL & 67 & 103 & 127 & 233 & 230 & 760 \\
\hline
\end{tabular}




\section{GENERAL RESULTS}

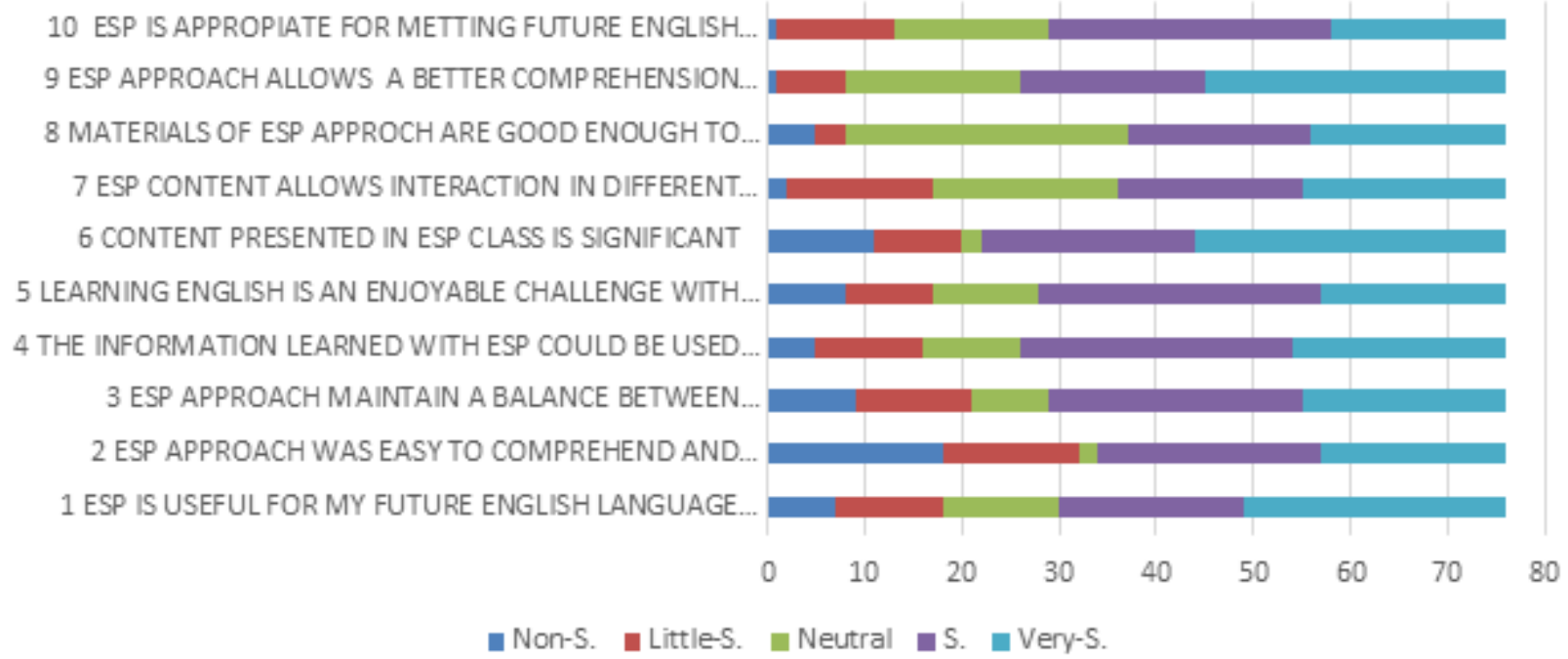

Graph 1: generated from the table 1

In this graph, the answers of the participants had been addressed in order to analyze students' responses to each of the ten categories. In brief, the ten categories show that participants believe that several aspects of the ESP methodology were partially achieved and a wide range of the students are satisfied with the implementation of the ESP instruction they have been subjected to, which were provided to cover their needs in the use of ESP to learn English language for specific purposes. Besides, the data analysis shows that the overall results are inclined towards the satisfactory and very satisfactory variables, which indicates that in agreement with many other studies that have been carried out in the same field to execute a Needs Analysis, the students' perceptions are considering ESP as a useful approach concerning the core characteristics of its methodology. Moreover, the graphic concerning the categories results about students' perceptions look with favor on the ESP methodology, which is a great result and it gives the researcher a guideline to understand the current situation in which the English instruction in the institution is.

After obtaining the data from the students, the following Needs Analysis was conducted according students' perceptions identified from the first questionnaire, following the indicators mentioned above.

\section{Phase 1: Describing the desired performance}

In ESP courses, all the classes must be prepared with the purpose of accomplishing the goals of their corresponding units, and these lessons always have to consider a clear focus based on students' needs. For West (1993), "in ESP, any strategy can be chosen to be used in the classroom 
according to the context, students, teaching standards and learning abilities." (West 1993: 10). However, ESP courses need to integrate the content and the language by designing a range of activities and tasks; as the materials play a crucial role in the fulfilment of this characteristic, through a good use of materials, teachers or instructors must prepare the students to carry outtasks they would perform in a real professional setting. For this reason, Dudley-Evans and St John (1998) have stated that ESP courses have to have a plan to provide the necessary materials for the appropriate course development as they explain "it is rarely possible to use a particular textbook without the need for supplementary material, and sometimes no suitable published material exists for certain of the identified needs." (Dudley-Evans \& St John, 1998: 14; as cited in Ureña, 2017: 204).

In addition, it is widely believed that the balance of the four language skills is essential in teaching ESP courses, but it almost always depends on students' needs and interests. Dudley-Evans and St. John (1998) point out that "ESP isolates the skills associated with study activities such as reading textbooks, articles, writing essays, listening to lectures." (p. 41). Moreover, ESP courses, in general, have to introduce essential vocabulary, teach a variety of strategies for language production and reception, and provide learners with significant input, like any other general English course. Additionally, the students have to receive feedback when they make mistakes, practice important grammar structures and know the principles of mechanics. From the above, it becomes evident that there is a significant similarity between the objectives established by Stern (1992) for language education and ESP core principles that must be achieved in the course.

\section{Phase 2: Determining the current performance.}

After reviewing the results of the questionnaire that focused on the principles of the ESP methodology, it has been deduced that, for more than half of the students, the ESP methodology is focused on their future English needs; however, a considerable part of the students do not comprehend the ESP methodology implemented in their classes. Moreover, students think that they may use what they have learned within the ESP class outside the classroom; however, the participants have also acknowledged that the program does not represent a great challenge for them as to what they learn. For the participants, ESP aids language learning and the materials are good enough to cover the students' specific needs in their area of study. Besides, the content does include their specific. Also, students agree that the knowledge acquired through the ESP courses can be used in different situations and outside the classroom. Thus, the ESP methodology implemented in the Medicine career has attempted to meet the requirements and match the principles of an ESP course, and the results are favorable to confirm that the courses have been successfully implemented.

\section{Phrase 3: Describing performance, gaps and causes} ESP future English language needs

In terms of performance, the data analyzed in table shows that 46 out of the 76 participants believe 
ESP approach implementation so far has met their future language needs. On the other hand, 30 participants believe the course and syllabus implemented at Medicine career do not help them achieve their future language needs completely. The analysis of the needs of the participants for this investigation shows that the ESP courses complete and boost the achievement of the students' language needs for their future development in the professional field. In addition, regarding the causes in this needs analysis, it can be stated that the curriculum has been designed to meet institution needs without considering students' real language needs or perceptions about their needs.

\section{ESP Content}

The analysis of data gathered for this investigation also lays emphasis on the ESP content in terms of performance, needs, and causes. In terms of performance, the data analysis from table 1 shows that for fifty-four students, the ESP content is significant. Moreover, for thirty-nine students, the materials help them with the learning process, as they are rated as appropriate for the ESP courses. In addition, content must meet students' specific needs. Thus, students can make a distinction between ESP and other methodologies. For that to happen, the teachers must present a wide range of materials selected for the specific area of study. Finally, in terms of the causes analyzed for this Needs Analysis process, the results show that the ESP curriculum was implemented without considering specific learning needs. As a consequence, the content and materials selected for this course are not oriented to accomplishing students' specific needs.

\section{ESP Language skills}

In relation to performance, the results of the Needs Analysis in this investigation show that the ESP approach provides opportunities for students to use the four language skills more than other methodologies. However, each unit focuses on a specific skill, although learners are not aware of this. In terms of the needs, the results show that there are different ways to use English Language skills according a specific purpose; in this sense, the program emphasizes the focus on a specific skill for each Unit. Finally, in relation to the causes for this Needs Analysis, activities presented for the students are not designed taking into account a specific language skill.

\section{ESP usage}

In this category, the ESP usage was analyzed by means of the Needs Analysis conducted for this scientific article. The results show that, for performance, the participants agree that the knowledge acquired in the ESP courses can be used in different situations, boosting their language usage, but just a little bit more than half of the students are capable of understanding the content presented for this purpose. In terms of needs, the ESP knowledge must be versatile for being used in the specific area of study inside the classroom and also outside for job performing situations.

\section{Consequence}

After describing the performance gaps and causes regarding the core principles of ESP, the 
following hypothetical consequence has been stated: students will consider the ESP methodology as better than other old-fashioned methodologies to learn English. But, almost half of the students consider it a difficult to handle and use.

\section{Phase 4: Identifying solutions}

The analysis conducted in terms of phase 4 displays the current situation of the institution in terms of the current curriculum implemented. The lack of previous information about Needs Analysis conducted in ESP curricula in this institution limits this case study information, results, and analysis. Moreover, no ESP curriculum has been applied for Medicine career.

The following table summarizes the causes that have been identified in the previous step and recommends a possible solution for each one of them.

Table 2. Causes and solutions for the ESP courses

\section{CAUSE (LACKS)}

Current curriculum does not consider students' language needs for their future development in the professional field.

Current curriculum does not consider specific learning needs and it does not provide the appropriate materials.

Current Activities are not designed taking into account a specific language skill.

Lack of opportunities to use language inside and outside classroom.

\section{POSSIBLE SOLUTION}

Needs Analysis must be done in order to identify students' future professional needs for their professional field.

ESP curriculum must consider specific learning needs and provide the necessary materials for students to archive their language needs.

In ESP the skills must be segregated considering the students professional need

ESP program has to consider activities inside and outside the classroom. "Real Situations"

Hence, what follows is the analysis of these possible solutions based on the problematic causes of the inefficiency of the ESP curriculum implemented at Escuela Superior Politécnica de Chimborazo, for Medicine career.

\section{Conclusions.}

- Results of the study indicate that, in general, the students have a non-satisfactory perception towards learning English through instruction based on the ESP methodology which has been applied in the English course at Medicine career. The data analyzed in this study also revealed that the students firmly believe that their English instruction using the ESP method is different from other English teaching methodologies. 
- The participants expressed they were satisfied with their ESP instruction regarding its principles. For this reason, the overall result must be used with discretion. These results that were gathered before the implementation of Needs Analysis in the Medicine career support the theories presented by authors like Hutchinson and Waters (1987) and DudleyEvans and St. John, (1998), who believe that the Needs Analysis must be the first step in the implementation of an ESP. Moreover, previous research conducted in the same field show that it is fundamental for teachers and educational authorities to include "an ongoing system of evaluation, aiming to provide information for improving the program itself through the introduction of changes that are deemed necessary

- Through the Needs Analysis, the research was able to identify the primary needs of the students, the causes for which these needs emerged, what the students want to cover these needs and finally to determine a possible consequence of what would happen if the students' needs were not taken into consideration.

- As for the limitations of this study, the researcher has concluded that time constraints were an important factor in carrying out this investigation. This is largely due to the time allotted to collect the data. In addition, a pedagogical intervention would lead to proving that the Needs Analysis is indeed an essential tool which must be used before any ESP course is implemented. This was not possible due to time constraints, as the ESP course which the participants were part of could not be intervened in for an intervention; the reason was that the courses implemented have a tight schedule and syllabus which must be completed before the end of each semester. Therefore, a limitation of this study concerns a subsequent phase in which the Needs Analysis results could be used to design and implement an ESP course.

- The overall findings of this investigation correspond with the literature in that, Hutchinson and Waters (1987), Brown (2009), and West (1994) and many other authors consider how a Needs Analysis for an ESP must be performed, the characteristics, variables, and core principles that have to be considered. From what was analyzed and studied in this research and from my perspective as a researcher, in agreement with many authors, Needs Analysis should be the first step that must be implemented in an ESP syllabus in order to link the present students' needs with their needs in the future field of study and most importantly to clearly identify students' needs, lack and wants in relation with the course presented for the students. Moreover, just after analyzing the students' needs and determining the objectives of the English course, it is possible to select specific materials that relate to the field of study and specific needs of the students. Thus, Needs Analysis is the core through which we can develop content related to the curriculum needs and appropriate teaching methods; in addition, we can make a proper selection of materials to increase the students' academic success as well as in their future professional field. 
- Finally, although the process of development and implementation of the Needs Analysis takes a long time, this should be carried out once a year or at least once as soon as the corresponding syllabus has been designed for the program. Neglecting this process is something that an educational institution that applies the ESP methodology cannot allow.

\section{References}

Berg, R. I. (1972). Factor analysis. American Statistician. https://doi.org/10.1080/00031305.1972.10477372

Berkeley lab (2017) Needs analysis for an English for Specific Purposes (ESP) course. Retrieved from https://Berkeley lab. Training.com

Brown, J. (2002). Training needs assessment: A must for developing an effective training program. Public Personnel Management. https://doi.org/10.1177/009102600203100412

Chapelle, C. A., \& Duff, P. A. (2003). Some Guidelines for Conducting Quantitative and Qualitative Research in TESOL. TESOL Quarterly. https://doi.org/10.2307/3588471

Creswell, J. W. (1994). Quantitative and qualitative paradigm assumptions. Research Design: Qualitative and Quantitative Approaches. https://doi.org/10.1186/cc12892

Dudley, E. a. (1998). Developments in ESP a Multi-Disciplinary Approach. Cambridge: Cambridge University Press.

Dudley-Evans, T. (1998a). An overview of ESP in the 1990s. The Japan Conference on English for Specific Purposes Proceedings, 4-5.

Dudley-Evans, T. (1998b). Genre analysis: a key to a theory of ESP? Iberica. https://doi.org/10.1007/s13277-013-0721-3

Dudley-Evans, T., Jo, M., \& John, S. (1998). Developments in ESP: A multi-disciplinary approach. In Developments in ESP: A multi-disciplinary approach.

Hood B. (2009). The learner as needs analyst: The use of participatory appraisal in the EAP reading classroom. English for Specific Purposes. https://doi.org/10.1016/j.esp.2006.01.003

Mackay, D. G. (1978). Derivational rules and the internal lexicon. Journal of Verbal Learning and Verbal Behavior. https://doi.org/10.1016/S0022-5371(78)90529-7

Mackay, R. a. (1978). English for Specific Purposes: A case Study Approach. London: Longman.

Merriam, S. B. (1998). Merriam S 1998 S1.pdf. In Qualitative Research and Case Study Applications in Education. 
Vol. 3, N², p.118-132, abril - junio, 2020

Miller, G. (2011). ESP paper rekindles discussion about statistics. Science. https://doi.org/10.1126/science.331.6015.272

Robinson, P. (1980). English for Specific Purposes. Oxford: Pergamon Press.

Stern, H. (1992). Issues and Options in Language Teaching. Oxford: Oxford University Press.

Stake, R. E. (1995). The Unique Case. In The Art of Case Study Research. https://doi.org/10.1073/pnas.172390399

West, R. (1993). "Needs Analysis in Language Teaching. In Language Teaching, pp. 1-15 .

West, R. (1994). Needs analysis in language teaching. Language Teaching. https://doi.org/10.1017/S0261444800007527

Yin, R. K. (2003). Applications of case study research. Applied Social Research Methods series. https://doi.org/10.1097/FCH.0b013e31822dda9e

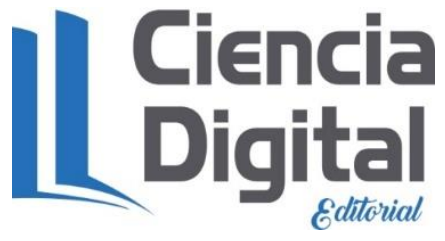




\section{PARA CITAR EL ARTÍCULO INDEXADO.}

Ureña Lara, D. A., Campaña Días, D. C., \& Cardenas Moyano, M. Y. (2020). Análisis de necesidades: caso de estudio, para la innovación curricular en un curso ESP. ConcienciaDigital, 3(1.1), 118-132. https://doi.org/10.33262/concienciadigital.v3i1.1.1135

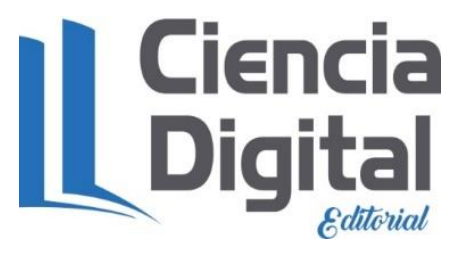

El artículo que se publica es de exclusiva responsabilidad de los autores y no necesariamente reflejan el pensamiento de la Revista Conciencia Digital.

El artículo queda en propiedad de la revista y, por tanto, su publicación parcial y/o total en otro medio tiene que ser autorizado por el director de la Revista Conciencia Digital.

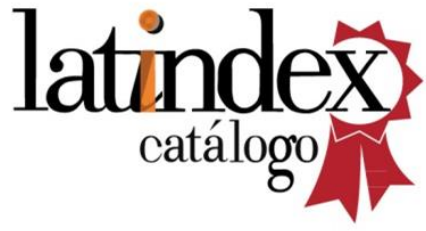
Conciencia

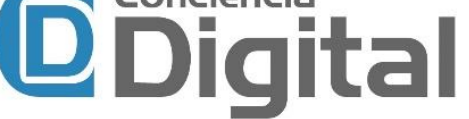

